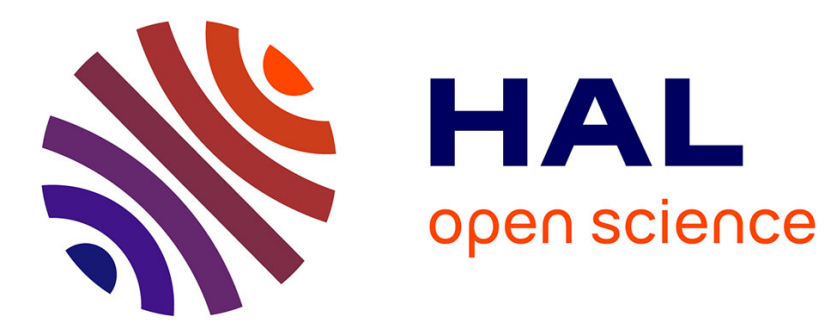

\title{
Seasonal migrations of four individual bar-headed geese from Kyrgyzstan followed by satellite telemetry
}

\author{
Ulrich Köppen, Alexander Petrovich Yakovlev, Raimund Barth, Michael
}

Kaatz, Peter Berthold

\section{- To cite this version:}

Ulrich Köppen, Alexander Petrovich Yakovlev, Raimund Barth, Michael Kaatz, Peter Berthold. Seasonal migrations of four individual bar-headed geese from Kyrgyzstan followed by satellite telemetry. Journal für Ornithologie $=$ Journal of Ornithology, 2010, 151 (3), pp.703-712. 10.1007/s10336-0100492-1 . hal-00575245

\section{HAL Id: hal-00575245 \\ https://hal.science/hal-00575245}

Submitted on 10 Mar 2011

HAL is a multi-disciplinary open access archive for the deposit and dissemination of scientific research documents, whether they are published or not. The documents may come from teaching and research institutions in France or abroad, or from public or private research centers.
L'archive ouverte pluridisciplinaire HAL, est destinée au dépôt et à la diffusion de documents scientifiques de niveau recherche, publiés ou non, émanant des établissements d'enseignement et de recherche français ou étrangers, des laboratoires publics ou privés. 


\title{
Seasonal migrations of four individual bar-headed geese Anser indicus from Kyrgyzstan followed by satellite telemetry
}

\author{
Ulrich Köppen • Alexander Petrovich Yakovlev • \\ Raimund Barth $\cdot$ Michael Kaatz $\cdot$ Peter Berthold
}

Received: 20 January 2009/Revised: 3 January 2010/Accepted: 8 January 2010/Published online: 10 March 2010

(C) Dt. Ornithologen-Gesellschaft e.V. 2010

\begin{abstract}
The Kyrgyz population of the bar-headed goose Anser indicus has declined dramatically during the past decades. Human persecution during migration and habitat loss at stopover and wintering sites are commonly regarded as most serious threats. However, little is known about seasonal movements, migration routes, and wintering sites
\end{abstract}

Communicated by F. Bairlein.

\section{U. Köppen ( $\square)$}

Hiddensee Bird Ringing Centre,

State Office for Environment,

Nature Conservation and Geology

of Mecklenburg-Western Pomerania,

Badenstr. 18, 17439 Stralsund, Germany

e-mail: ulrich.koeppen@lung.mv-regierung.de

\author{
A. P. Yakovlev \\ Issyk Kul Biosphere Reservation, \\ 722324 Ananyevo, Kyrgysztan \\ e-mail: yakovlev_ecology@rambler.ru \\ R. Barth \\ Max Planck Institute for Ornithology, \\ Behavioural Ecology and Evolutionary Genetics, \\ Von der Tann Str. 7, 82346 Andechs, Germany \\ e-mail: barth@orn.mpg.de
}

\section{Kaatz}

Vogelschutzwarte Storchenhof Loburg e.V.,

Chausseestr. 18, 39279 Loburg, Germany

e-mail: michael.kaatz@storchenhof-loburg.de

\section{P. Berthold}

Max Planck Institute for Ornithology, Vogelwarte Radolfzell,

Schlossallee 2, Schloss Moeggingen,

78315 Radolfzell, Germany

e-mail: berthold@orn.mpg.de of the bar-headed geese from Kyrgyzstan, which represent the westernmost geographical population of the species. As part of a conservation project, which also included reinforcement of the wild population by the release of handreared juveniles, in late summer of 1998, five bar-headed geese, three wild adults and two hand-reared goslings, were fitted with sun-powered satellite transmitters in order to track their movements from Lake Son Kul and Lake Chatyr $\mathrm{Kul}$ in Kyrgyzstan. The five individuals contributed very unevenly to the more than 5,000 signals in total that were received from the French ARGOS system: one failed after 8 weeks, while another one was tracked for more than 2 years. The four geese contributing to this study followed three completely different migration routes leading to their wintering areas in Pakistan, India and Uzbekistan, while stopover areas were situated in southern Tajikistan and in western Tibet. Both in autumn and spring the adult birds migrated distances of $1,280-1,550 \mathrm{~km}$ in two steps, with stopover periods of 32-46 days (autumn) and 16-23 days (spring). Flight speeds of up to $680 \mathrm{~km}$ per actual migration day were recorded regularly, even during crossings of very high summits. A hand-reared juvenile flew non-stop for $790 \mathrm{~km}$ to southern Uzbekistan and even visited southernmost Turkmenistan, where the species is very rarely seen. The timing of migration varied considerably between individuals but also for the same individual between years. We compare our tracking results with previous findings (field observations, ring recoveries, and satellite tracking results) and discuss them with respect to migration over high-mountain habitats and a general migration strategy of the species.

Keywords Bar-headed goose - Anser indicus . Kyrgyzstan · Satellite telemetry - Migration routes · Stopover areas $\cdot$ Wintering areas 


\section{Introduction}

The bar-headed goose Anser indicus is a waterfowl species of high-mountain wetlands, with a fragmented breeding range from Kyrgyzstan in the west to Manchuria in the east and southward to northern India (Del Hoyo et al. 1992; Miyabayashi and Mundkur 1999; McKinnon and Phillips 2000).

Perennou et al. (1994) estimated an increasing overall population of approximately 50,000 individuals, while Javed et al. (2000) argued that positive population trends may rather be due to increasing counting activities. The species had been listed as near threatened by Collar and Andrew (1988) but was deleted from later lists of globally threatened and near threatened bird species (Collar et al. 1994; BirdLife International 2000). In Russia, Kyrgyzstan, and Tajikistan the bar-headed goose has already been regarded as severely endangered for a long time (Abdusalyamov 1971; Selesnev 1976; Borodin et al. 1985; Yakovlev 1997; Danilov-Danilian 2001, http://birds.krasu.ru).

The only two breeding sites currently left in Kyrgyzstan are Lake Son Kul and Lake Chatyr Kul in the Tien Shan mountains at altitudes of 3,016 m and 3,539 m (Kydyraliev 1967, 1973, Fig. 1).

A total of 170-190 breeding pairs in Kyrgyzstan in the early 1950s had declined to approximately 100 individuals in the late 1990s (Yakovlev 1997). Human persecution and habitat deterioration are assumed to be the most serious threats to the geese during migration and at wintering sites (Javed et al. 2000; Del Hoyo et al. 1992).

Seasonal movements, migration routes, and wintering grounds of most geographical populations of the bar-

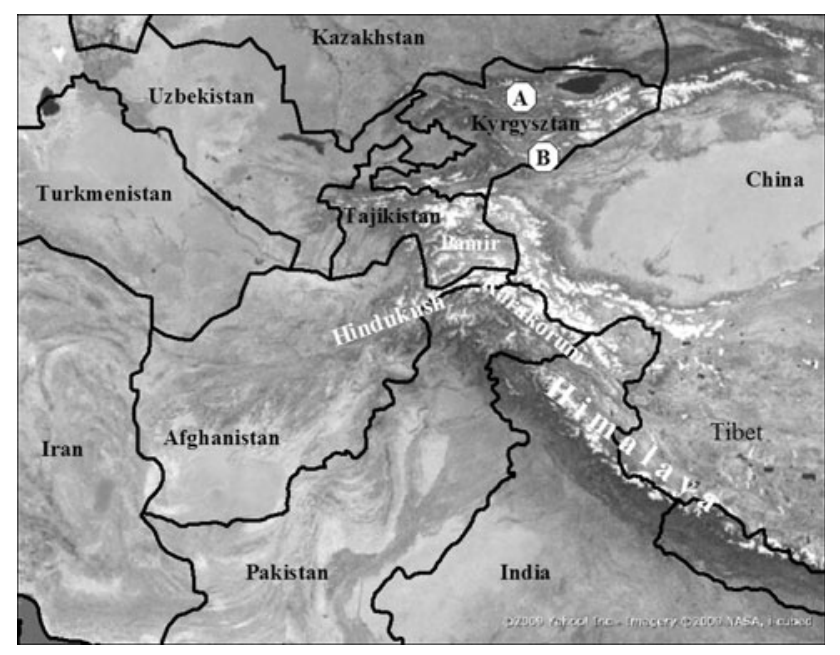

Fig. 1 Map of Central Asia, with main high mountain ranges and sites where transmitters were fitted to bar-headed geese. A Lake Son Kul, $B$ Lake Chatyr Kul headed goose have been little investigated (McClure 1998). With regard to the Kyrgyz population, it was concluded from ring recoveries (Kydyraliev and Abdusalyamov 1979) that the geese spend winters in the Indus river floodplains in Pakistan, while particular migration habits have remained unknown until now.

Consequently, a joint German-Kyrgyz project, "Research Programme Bar-headed Goose", was aimed at (1) the investigation of migration habits of the Kyrgyz population in detail and (2) obtaining evidence that goslings that are hand-reared and released to the wild, as part of a special conservation project in Kyrgyzstan (Yakovlev 1997), would be able to join the wild population and act as recruiters.

Satellite telemetry was regarded as an appropriate tool to achieve those aims. This method has already been applied successfully for a large variety of bird species (see Berthold 2007 for review). Most instructive with respect to our study were results obtained from brent geese Branta bernicla (Gudmundsson et al. 1995) and lesser whitefronted geese Anser erythropus (Lorentsen et al. 1998). Satellite transmitters were used for the first time on barheaded geese by Javed et al. (2000), who investigated seasonal movements of individuals wintering in Keoladeo National Park, Bharatpur, in Rajasthan, India. The study by Javed et al. (2000), as well as a further satellite tracking study undertaken in 2005 [U.S. Geological Survey (USGS) 2006], revealed that birds tracked from wintering grounds in India and Nepal were breeders from Tibet. Until now, no-one has ever tracked bar-headed geese from their breeding grounds to investigate migration features, nor has satellite tracking ever been used for the Kyrgyz population, which is the westernmost population of the species (Kear 2005).

Here, we present the results of the satellite tracking of three adult and one juvenile bar-headed geese from the Kyrgyz population, with respect to time patterns and geographical course of their migration cycle.

\section{Methods and material}

At the end of July 1998, when we visited Lakes Son Kul and Chatyr Kul to conduct fieldwork for this study, all the observed adult bar-headed geese were flightless due to flight-feather moult. Therefore, three adult wild birds could easily be caught by the use of a small motor boat.

Transmitters were attached to these three adult geese and to two hand-reared goslings which had been transported to Lake Son Kul for release there. For dates and sites of capture/release and status of the tracked individuals, see Table 1 . Sexes of the adult wild birds were determined by cloacal inspection. 
Table 1 Individual status and periods of data collection for bar-headed geese tracked by satellite transmitters from Lake Son Kul and Lake Chatyr Kul in Kyrgyzstan ( $M$ male)

\begin{tabular}{llllll}
\hline Individual & Sex & Age/status & Date and site of release & $\begin{array}{l}\text { Date of last signal } \\
\text { included in this study }\end{array}$ & $\begin{array}{l}\text { No. of days with signals } \\
\text { included in this study }\end{array}$ \\
\hline 14545 & M & Wild adult, no pair- bond & 30.07 .1998 , Chatyr Kul & 05.12 .1998 & 135 \\
14549 & $?$ & Hand-reared fledgling & 25.07 .1998$, Son Kul & 24.09 .1998 & None \\
14550 & M & Wild adult breeder, mated, five goslings & 25.07 .1998 , Son Kul & 05.04 .1999 & 252 \\
14553 & M & Wild adult breeder, mated, six goslings & 30.07 .1998$, Chatyr Kul & 18.09 .2000 & 810 \\
14554 & $?$ & Hand-reared fledgling & 25.07 .1998$, Son Kul & 05.09 .1999 & 411 \\
\hline
\end{tabular}

We used microwave platform terminal transmitters (PTT-100) powered by solar panels, which were attached to the birds like back-packs and fixed by thin harnesses of plastic material. The harnesses were enclosed in narrow tubes of smooth Teflon tissue to avoid any destruction of feathers or skin. Great care was taken to ensure that any dislocation of the transmitters was excluded and that the threads were placed well below the body feathers so that the normal protection functions of the plumage were not impaired.

The transmitters weighed approximately $35 \mathrm{~g}$, so that the additional load borne by the geese was about $45 \mathrm{~g}$, including the threads. Altogether, this equipment amounted to approximately $2 \%$ of the normal adult bird's body weight and maximally $3 \%$ for the young birds (our own data, see also Dunning 1993). The signals sent continously by the transmitters were received via the French ARGOS satellite system. The periods during which the signals indicated that the birds were alive and their transmitters functioning well lasted between 60 days and 810 days (Table 1). Because one juvenile bird did not leave the site where it was released until failure of its transmitter (14549), data for this bird are not presented here.

The transmitters on the four remaining birds provided different numbers of locations per time unit, while the quality of the location data differed widely according to the particular accuracy classes of the ARGOS system. Those accuracy classes define deviations from real geographical positions as follows: class $3<250 \mathrm{~m}$ [ \pm 1 standard deviation (SD)], class $2=250-500 \mathrm{~m}( \pm 1$ SD), class $1=$ between 500 and $1,500 \mathrm{~m}$, class $0>1,500 \mathrm{~m}$ (no upper estimate), classes $\mathrm{A}$ and $\mathrm{B}=$ no accuracy estimation, location accuracy has to be judged by user, and $\mathrm{Z}=$ invalid location (ARGOS 2007).

As has been found in other satellite telemetry studies (e.g. Lorentsen et al. 1998, own data), in our study, out of the total of 5,037 locations received from the four transmitters, only $604(11.96 \%)$ were of ARGOS accuracy classes 1, 2 and 3 (10.16\%, 1.41\%, and 0.39\%). Hence, according to the ARGOS user manual (ARGOS 2007) almost $90 \%$ of the locations were of limited value for the purposes of this study. To obtain more precise locations from the available data set, we used a procedure developed by Kaatz (2004), who analysed 8,979 cases where real geographical positions, i.e. geographical coordinates by a global positioning system (GPS), of transmitter-tagged German white storks Ciconia ciconia were compared with the respective ARGOS coordinates. He found (1) that the 'accuracy of location estimate' classes of ARGOS in many cases did not reflect the true relationships (see also Hays et al. 2001), and (2) that there were significant correlations between the real accuracy of geographical coordinates and certain parameters provided by each transmitter signal, in particular the parameter 'number of successful plausibility checks' (NOPC). These allow calculation of the extent by which the ARGOS coordinates deviate from those of the real position of the transmitter. Estimating the accuracy of the locations in this way allowed many more locations to be included than when based on ARGOS location accuracy classes exclusively. For the analyses, only locations with an upper limit of $50 \mathrm{~km}$ deviation from the positions estimated after Kaatz (2004) were accepted.

Spatial interpretation of the data was performed with ATLAS GIS software (Strategic Mapping Inc., Santa Clara, CA, USA).

\section{Results}

Geographical patterns of migration

The locations plotted in Fig. 2 show three geographical patterns that markedly differ from each other with regard to direction of autumnal departure and the geographical situation of stopover and wintering areas. Five different stopover areas (four in autumn and a further one in spring) and five different wintering areas used by these four birds can be distinguished. These areas, denoted in Fig. 2 by Roman numerals $\mathrm{I}$ to $\mathrm{X}$, can be roughly described as follows: 

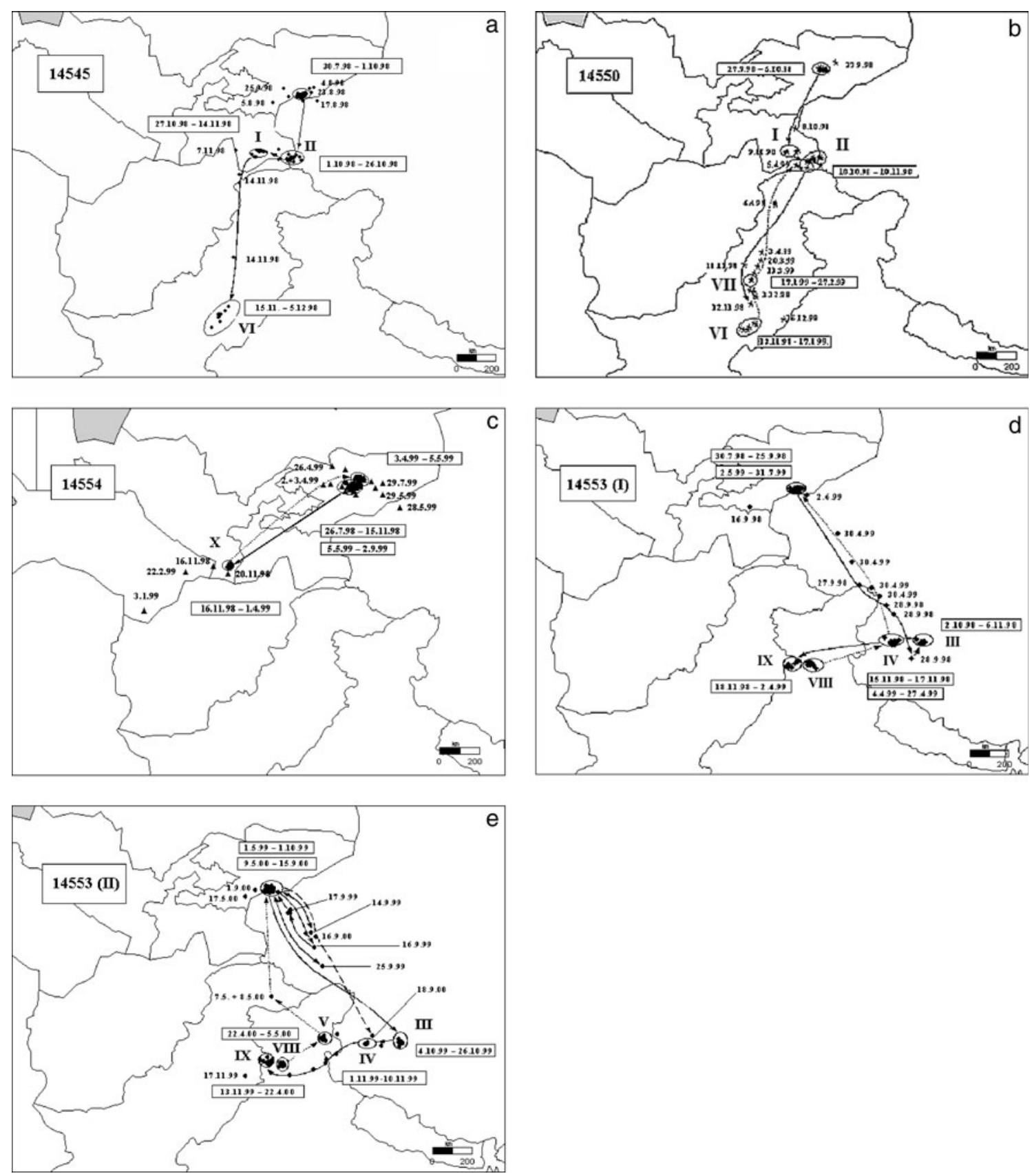

Fig. 2 Geographical patterns of movements of the four individual bar-headed geese as revealed by satellite tracking. Roman numerals denote different stopover and wintering areas; for details see text

Stopover areas:

(I) Lakes and rivers of the southern Pamir range, e.g. Yashil Kul (37.45N 73.00E), Alichur river, southern Tajikistan

(II) Rivers Oksu and Pyandsh (37.20N 74.25E) in 'Little Pamir' range, Tajikistan-Afghanistan-China border zone
(III) Lake Mindam Tso near Munak Thok (33.09N 81.21E), western Tibet

(IV) River valleys between Rutog and Rabang (33.03N 80.29E), western Tibet

(V) Indus river valley in the Zaskar mountains., Lake Tsokr and Lake Chumo (33.20N 78.00E), northwestern India 
Wintering areas:

(VI) Indus river floodplains between inflow region of Panynad river $(28.45 \mathrm{~N} 70.35 \mathrm{E})$ and Taunsa Barrage $(30.43 \mathrm{~N} 70.41 \mathrm{E})$, central Pakistan

(VII) Indus flood plains south of Dera Ismail Khan (31.48N 70.55E), central Pakistan

(VIII) River valleys (Ravi, Degh and Chenab), north of Amritsar (31.35N 74.56E), and Beas reservoir (31.57N 75.50E), north-western India

(IX) River valleys (Degh, Ravi) (31.53N 74.35E) north of Lahore, north-eastern Pakistan

(X) Valley of Vakhsh river, north of Kurgan-Tyube (37.50N 68.46E), southern Uzbekistan

All three adult birds (14550, 14545, 14553) showed a two-step pattern during autumn migration. While 14550 and 14545 left their breeding sites in a south to southwesterly direction to reach areas I and II (Fig. 2a, b), 14553 went in all three recorded seasons in a south-easterly direction to stopover area III in western Tibet (Fig. 2d, e). The first migration step of the latter was approximately four times longer than that of the other two adults. In September 199914553 performed several rather long premigration flights before finally leaving the breeding site (Fig. 2e). All three adult birds reached their wintering areas by a second migration step, which led 14545 and 14550 from southern Tajikistan (areas I and II) directly southwards to the middle course of the Indus river in central Pakistan (areas VI and VII), and 14553 from Tibet (areas II and IV) in a westerly direction to north-west India and the Lahore area in Pakistan (areas VIII and IX).

No. 14554, the hand-reared first-year bird, left the release site at Lake Son Kul in mid November in a southwesterly direction to reach area $\mathrm{X}$ by a non-stop flight within 1 day (Fig. 2c).
During the stopover periods, which lasted between 32 days and 45 days, the birds generally did not stay at certain sites but switched between suitable sites within a circle of up to about $200 \mathrm{~km}$. This was the case with 14553 (adult male breeder from Chatyr Kul) in Tibet (areas III and IV) as well as with both 14545 (unpaired adult from Chatyr Kul) and 14550 (adult male breeder from Son Kul) in southern Tajikistan (areas I and II).

After arrival at wintering grounds the birds changed their sites rather than staying at one particular site for a longer period. Single long-distance round-flights occurred also in winter: On 16 December 1998, 14550 flew from area IV about $300 \mathrm{~km}$ west to Islam Barrage $(29.50 \mathrm{~N}$ 72.31E) close to the Indian border and returned on the same day (Fig. 2a). On 3 January 199914554 flew about $550 \mathrm{~km}$ south west to the valley of the river Murgab near Kalai-Mor (35.40N 62.32E) in Turkmenistan, and, on 22 February, even to the Karakum Canal near Karamet Niyaz (37.37N 64.32E), in Turkmenistan (Fig. 2c).

Migration movements in spring could be completely tracked only for two birds. While the transmitter of 14545 had already failed in the bird's presumed wintering area (VI), signals were received from 14550 until after the bird had crossed the Hindukush and had reached area II (5 April 1999), where they ceased. In spring 14553 again showed a two-step migration pattern like that in autumn (Fig. 2d, e), although the bird used different geographical routes in the two recorded seasons. Whereas, in spring 1999, it followed precisely the autumn route back, in the following year the bird did not cross the Himalayas but headed north to area $\mathrm{V}$, where it rested for 16 days in April and early May (Fig. 2e).

As in autumn 1998, 14554 went back in spring 1999 by a single non-stop flight from southern Uzbekistan (area X)

Table 2 Timing and duration of movement and stopover periods during seasonal migration, and migration distances covered by four bar-headed geese as revealed by satellite tracking

\begin{tabular}{|c|c|c|c|c|c|c|c|c|c|c|c|c|}
\hline \multirow[t]{2}{*}{ Individual } & \multicolumn{6}{|l|}{ Autumn } & \multicolumn{6}{|l|}{ Spring } \\
\hline & $\begin{array}{l}\text { Departure } \\
\text { from } \\
\text { release site }\end{array}$ & $\begin{array}{l}\text { Arrival at } \\
\text { wintering } \\
\text { area }\end{array}$ & $\begin{array}{l}\text { Duration } \\
\text { (days) }\end{array}$ & $\begin{array}{l}\text { Distance } \\
(\mathrm{km})\end{array}$ & $\begin{array}{l}\text { Stopover } \\
\text { days }(n)\end{array}$ & $\begin{array}{l}\text { Speed }(\mathrm{km} / \\
\text { migration } \\
\text { day) }\end{array}$ & $\begin{array}{l}\text { Departure } \\
\text { from wintering } \\
\text { area }\end{array}$ & $\begin{array}{l}\text { Arrival at } \\
\text { release } \\
\text { site }\end{array}$ & $\begin{array}{l}\text { Duration } \\
\text { (days) }\end{array}$ & $\begin{array}{l}\text { Distance } \\
(\mathrm{km})\end{array}$ & $\begin{array}{l}\text { Stopover } \\
\text { days }(n)\end{array}$ & $\begin{array}{l}\text { Speed }(\mathrm{km} / \\
\text { migration } \\
\text { day) }\end{array}$ \\
\hline 14545 & 01.10 .1998 & 15.11 & 45 & 1,360 & 43 & 680 & & & & & & \\
\hline 14550 & 05.10 .1998 & 13.11 & 38 & 1,550 & 32 & 258 & 03.04 & $05.04^{\mathrm{b}}$ & 2 & $1,020^{\mathrm{a}}$ & 0 & 510 \\
\hline 14554 & 15.11 .1998 & 16.11 & 1 & 790 & 0 & 790 & 01.04 & 02.04 & 1 & 720 & 0 & 720 \\
\hline \multirow[t]{3}{*}{14553} & 25.09.1998 & 18.11 & 53 & 1,280 & 45 & 160 & 02.04 & 02.05 & 30 & 1,280 & 23 & 183 \\
\hline & 01.10 .1999 & 13.11 & 43 & 1,280 & 37 & 213 & 21.04 & 09.05 & 18 & 1,315 & 16 & 657 \\
\hline & 15.09 .2000 & $18.09^{\mathrm{a}}$ & 3 & 920 & 0 & 307 & & & & & & \\
\hline
\end{tabular}

${ }^{a}$ Date of final signal from 14553 when the bird had reached area IV in Tibet

b Date of final signal from 14550 when the bird had reached north-eastern Afghanistan, near area I 
to the Cholpon river valley $(42.13 \mathrm{~N} 75.19 \mathrm{E})$, which is $50 \mathrm{~km}$ north of the release site at Lake Son Kul in Kyrgyzstan.

Timing and duration of migration

Although the dates of departure from the release sites in autumn 1999 differed between individuals by up to 51 days, the arrival dates at the wintering areas cited above differed only by a maximum of 5 days (Table 2). This time, synchrony was achieved by very flexible lengths of stopover periods, ranging from a maximum of 45 days to almost non-stop migration behaviour as shown by 14554 both in autumn and in spring migration. The maximum year-to-year variation of departure date of the same individual (14553) was 16 days (Table 2).

In spring 1999 the three individuals still tracked at this time left their individual wintering areas at almost the same date in early April (1-3 April), although all three had spent the winter in completely different geographical areas (14554 in Uzbekistan, 14550 in central Pakistan, 14553 in north-eastern Pakistan), and therefore had to use completely different migration routes to get back to Kyrgyzstan. Owing to failure of the transmitter of 14550, the arrival dates at the site of release could be recorded only for two birds. While 14554, the hand-reared juvenile bird, had already reached Lake Son Kul on 2 April, 14553 arrived at its previous year's breeding site (Lake Chatyr Kul) exactly 1 month later. This was because 14553 rested in April 1999 for about 3 weeks in western Tibet (area IV, see above) before heading home.

Again, 14553 may serve as an example that also in spring the individual timing of migration can be highly variable. In 2000 the bird left its wintering area almost 3 weeks later than in the year before, and it arrived at Lake Chatyr Kul 1 week later (Table 2).

The highest daily flight distance was recorded for 14554 while it was migrating to its wintering area in Uzbekistan and back by non-stop flights of $790 \mathrm{~km} /$ day and $720 \mathrm{~km} /$ day, respectively (Fig. 3a). A similar value was reached by 14545 in autumn 1998 (Table 2, Fig 3a). For 14553, daily flight distances between about $400 \mathrm{~km}$ and about $700 \mathrm{~km}$ were observed in all of the three (partly) recorded migration cycles (Fig. 3b). As already shown in Fig. 2d, e, this bird completed its comparatively long migration steps to and from the stopover within 6-8 days in autumn and 2-7 days in spring (for the actual migration, see Table 2, Fig 3b), of which several days comprised low daily flight activity and (mostly) only one showed very high flight activity, with distances of 600 $700 \mathrm{~km}$ covered per day. A similar pattern of daily migration activity was shown by all four recorded
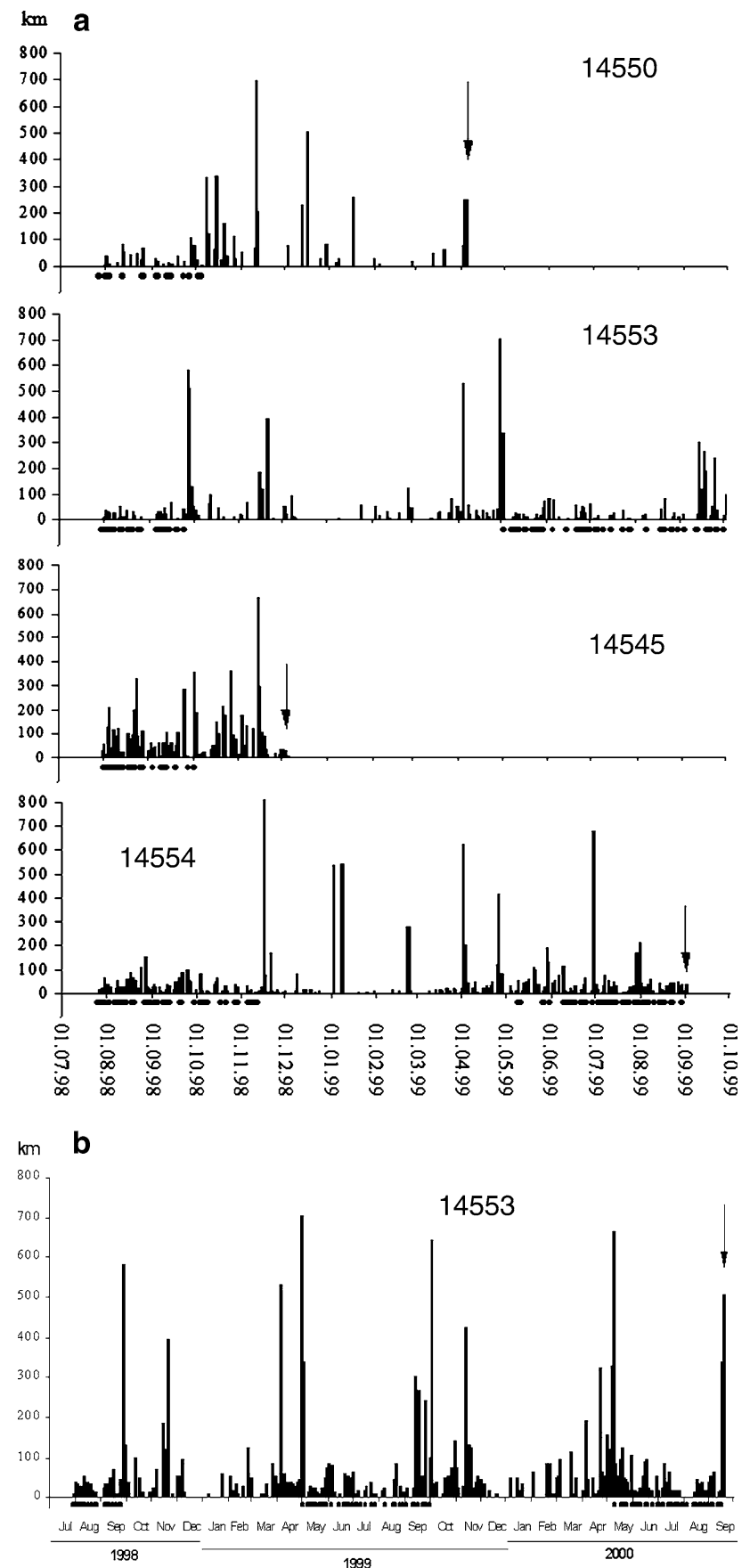

Fig. 3 a Daily flight activity patterns of the four individual barheaded geese from Kyrgyzstan between July 1998 and October 1999; dots below the $X$-axis indicate the bird present at site of release; the arrow denotes the date of the last signal included in this analysis. b Daily flight activity patterns of 14553 , breeding male from Chatyr Kul, between July 1998 and September 2000; dots below the $X$-axis indicate the bird present at site of release; the arrow denotes the date of the last signal included in this analysis

individuals (Fig. 3a). Owing to this particular behaviour, the average distances moved by the geese per 'real' migration day were much lower (Table 2). 


\section{Discussion}

Geographical and time patterns of migration

With reference to 38 recoveries of bar-headed geese ringed in Kyrgyzstan and Tajikistan, Kydyraliev and Abdusalyamov (1979) described roughly the same wintering areas as found by this study in the Indus valley in Pakistan (areas VI and VII). They concluded that birds from both countries are generally migrating directly southwards to common wintering grounds at the middle course of the Indus river in Pakistan. Roberts (1991) mentioned a further Moscowringed bar-headed goose of unknown origin, which was shot in March 1979 at the Kabul river near Nowshera in Pakistan, approximately $100 \mathrm{~km}$ west of the Khyber pass, where, in our study, 14550 passed during spring migration. It may be concluded that spring migration normally leads northwards, following the Indus valley until $35^{\circ}$ latitude, from where the geese continue to fly directly north as 14550 did in April 1999.

Field observations confirmed our findings on wintering sites of bar-headed geese in Pakistan. Besides the wellknown wintering sites around the Taunsa barrage, where 14545 and 14550 spent the winter of 1998/1999, Roberts (1991) points out that "small numbers regularly come down the Chenab river and sometimes stay on the sandbars upstream of Marala barrage...". In our study 14553 rested in that area, but it had come from Tibet by crossing the Himalayas (Ladakh Range) from east to west.

Another Moscow-ringed breeder from Lake Son Kul was shot near Lahore, Pakistan, which was regarded by Kydyraliev and Abdusalyamov (1979) as a noteworthy exception. In our study, 14553 was recorded in that region during two winters, so that this ring recovery did not merely indicate an exception but possibly reflected a common wintering area of the Kyrgyz population which still existed in the late 1990s. The same authors assumed northern Kashmir (upper Indus valley and river Gilgit) to be meaningful for Kyrgyz bar-headed geese during spring migration. In our study 14553 rested in this area in spring 2000.

Still unclear remain the origins of 17,000 bar-headed geese wintering in India (Ali and Ripley 1987; Miyabayashi and Mundkur 1999). Of 26 individuals ringed in winter near Bharatpur, none was reported back (McClure 1998). The two satellite-tracking studies performed until 2006 revealed that, amongst the winterers in Keoladeo National Park, Bharatpur, are breeders from south-western Tibet (Javed et al. 2000; USGS 2006). According to our results, the easternmost wintering site of bar-headed geese from Kyrgyzstan was in north-western India, approximately $75 \mathrm{~km}$ north of Amritsar (31.35N 74.56E), where 14553 spent two winters. In the latter province a winter population of 1,200 bar-headed geese was counted in 1996, while the species seems to be only a rare visitor in the Indian Punjab (Lopez and Mundkur 1997, The Asian waterfowl census 1994-1996. Results of the coordinated waterbird census and an overview of the status of wetlands in Asia. Kuala Lumpur. Wetlands International, unpublished report). According to our study, these winter populations may be composed at least in part of migrants from Kyrgyzstan.

Winter site fidelity, which is common, e.g., with bean geese in Central Europe (Rutschke 1997), was found for 14553 in this study over 2 years. Further research is needed to confirm this as a general phenomenon also in bar-headed geese.

For the first time, it could be shown that a hand-reared juvenile bar-headed goose (14554) had returned to the site of release after a complete migration cycle. Normally, the future prospects of juveniles, particularly in smaller goose species, strongly depend on extended parental care (Prevett and McInnes 1980 for snow geese Anser caerulescens) or at least on persistent association with family groups (Black and Owen 1989 for barnacle geese Branta leucopsis). Obviously, 14554 could achieve association within a period of almost 4 months between release at Lake Son Kul and leaving from there for autumn migration. Remarkably, 14554 was the only goose in our study that headed in a south-westerly direction to Uzbekistan. As early as April 1973 an adult bar-headed goose was reported from there, and had been ringed in Tajikistan (Kydyraliev and $\mathrm{Ab}$ dusalyamov 1979). However, as 14554 left Lake Son Kul 6 weeks later than the local breeder 14550, who flew in a southerly direction to Tajikistan, it is likely that 14554 was associated with some waterfowl other than bar-headed geese. Sub-adult bar-headed geese have repeatedly been reported to join greylag geese Anser anser, greater whitefronted geese Anser albifrons and also ruddy shelduck Tadorna ferruginea (Borshonov 1978; Syroechkovskyi and Rogacheva 1995), all species breeding or resting at Lake Son Kul as well.

Since the bar-headed goose was not included in the check-list of birds of Uzbekistan and Turkmenistan until 2000 (E. Kreuzberg-Muchina, pers. comm. 2001), it seems unlikely that the recorded migration and wintering behaviour of 14554 was shared by any other bar-headed geese.

Departure directions in autumn migration as well as stopover and wintering areas differ considerably within the Kyrgyz population. This means that endogenous preferences with respect to certain geographical migration patterns in the species hardly exist. The three different geographical patterns found in this study may therefore be interpreted as individually or group-confounded traditions. However, as demonstrated by 14553 , the route actually taken by an individual bird may vary from year to year 
within a broad frame of the preferred geographical migration pattern. Furthermore, the duration of resting periods within the two-step migration pattern (in spring and autumn) of adults varied from year to year by up to 2 weeks. It is noteworthy that the arrival dates at both wintering and breeding grounds varied much less in all recorded birds. It may be concluded that the choice of alternative migration routes, as well as the duration of resting periods, depends on external factors, presumably the currently prevailing weather conditions in the species' high-mountain habitats. For barnacle geese, it has recently been shown that the migratory behaviour of individuals even from the same breeding colony may vary greatly and can be adjusted individually from year to year (Eichhorn et al. 2009).

\section{General migration strategy}

As bar-headed geese have been reported to cross the Himalayas at elevations well above 8,000 m (Swan 1970), the species serves as a famous example for the ability of birds to overcome high barriers (e.g. Dolnik 1990; Elphick 1995). It has been shown that bar-headed geese are able to do so due to a higher myoglobin concentration at the beginning of migration than that of other goose species (Braunitzer and Hiebl 1988; Saunders and Fedde 1991). Additionally, they have slightly different haemoglobin structures, which increase the blood's binding affinity for oxygen (Zhang et al. 1996; for review see Butler and Bishop 2000). Newton (2008) states, with respect to the bar-headed goose, that "such birds can achieve feats of high-altitude performance that are shown by very few, if any other animals, and can do so without any time to acclimatise".

The bar-headed geese tracked in this study actually crossed mountain areas regardless of their height and did not avoid even very high summits. 14554 had to overcome the Tien Shan mountains and the Alai range, with summits up to 7,000 $\mathrm{m}$ above sea level. 14545 and 14550 crossed the eastern Hindukush range close to Tirich Mir mountain (36.18N 71.55E, 7,750 $\mathrm{m}$ above sea level). 14553 rested several times in the westernmost Xinjiang province of China, close to Mt. Godwin Austen (K2) (35.53N 76.32E) at elevations of $5,000 \mathrm{~m}$ above sea level. In mid-November, 1998, this bird flew in a $500 \mathrm{~km}$ non-stop flight over the Ladakh Range (Himalayas), reaching elevations of 6,000 m, and, in spring 2000, 14553 flew from Skardu, Northern Kashmir (35.18N 75.44E) in a $650 \mathrm{~km}$ non-stop flight over the Karakorum mountains, close to the Nanga Parbat mountain $(8,126 \mathrm{~m}$ above sea level), back to its breeding site at Lake Chatyr Kul.

The environmental conditions under which such movements are undertaken are only predictable in a broad long- term frame, but, in the short-term view, they may get worse in an unforeseeable and dramatic manner. This requires a general migration strategy that allows the birds to escape to more suitable places by very fast flights necessarily leading over a large scale of altitudes in very short times. Barheaded geese have been experimentally proven even to withstand simulated high-altitude conditions of slightly over $12 \mathrm{~km}$ (Black and Tenny 1980), which, by far, exceeds the tolerance limits of most mammals and many other bird species.

Nevertheless, at lower elevations, topographic features such as the Indus river valley in Pakistan and in northern Kashmir obviously played an important role as geographical guidelines. In contrast to other species of geese of the northern hemisphere, e.g. the barnacle goose (Black and Owen 1989), bar-headed goose migration seems not to be funnelled to small and distinct wintering areas, which was assumed by Kydyraliev and Abdusalyamov (1979) and also by Knystaustas (1993). Instead, it shows the character of a wide-front migration, as suggested by Javed et al. (2000), leading to wintering grounds within a broad belt from central Pakistan to western Myanmar (e.g. Kear 2005). These findings have been confirmed by the results published by USGS (2006), in which the breeding sites of birds wintering in Nepal were clearly separated from those wintering in the more westerly Bharatpur area of India. In recent times this distribution has increasingly been linked with agricultural crops available for winter feeding (e.g. Choudhury 1997).

Kyrgyz bar-headed geese rest during migration at sites where conspecifics regularly are resident (e.g. Ming and Dai 1999; Lu 1997; Bishop et al. 1997). Hence, they perform a classical leap-frog migration, in which migrating populations of a species overfly resident ones. A pattern like this has been regarded as a special case of differential migration on species' level (Newton 2008).

The series of pre-migration flights of 14553 in September 1999, when the bird flew at least $2,000 \mathrm{~km}$ forth and back along its last year's migration route with apparently no gain in terms of true migration, remains unexplained. Similarly, the very fast round-trip flights in winter to sites at remarkable distances from the otherwise small wintering area of 14550 and 14554, can hardly be explained by 'Winterflucht' due to sudden harsher winter conditions, as the birds returned after only 2 days. The occurrence of such undirected long-distance flights documented in this study might explain why bar-headed geese have repeatedly been observed very far away from the traditional migration routes of the species, e.g. in the Bolzshezemelskaya tundra and at the Kanin Peninsula in northwest Russia (e.g. Mineev and Mineev 2000), at the Taimyr peninsula in northern Siberia (Borshonov 1978), and in the Baikal region (Melnikov 1997). 


\section{Zusammenfassung}

Saisonale Raum-Zeit-Muster von vier kirgisischen Streifengänsen Anser indicus anhand satellitentelemetrischer Daten

Der Brutbestand der Streifengans Anser indicus in Kirgistan hat im Laufe der letzten Jahrzehnte dramatisch abgenommen. Da in den Brutgebieten keine erkennbaren Veränderungen eintraten, werden massive Bejagung abseits der Brutgebiete sowie Verschlechterungen der ökologischen Bedingungen in den Rast- und Überwinterungsgebieten als Hauptfaktoren für den Bestandsrückgang angenommen. Allerdings sind die Zugwege wie auch die Rast- und Überwinterungsgebiete speziell der kirgisischen Population, welche die westlichste innerhalb des geschlossenen Verbreitungsgebietes der Art darstellt, nur sehr bruchstückhaft bekannt. Um den diesbezüglichen Wissensstand zu verbessern, wurden im Spätsommer 1998 im Rahmen eines staatlichen kirgisischen Artenschutzprojektes, das auch Bestandsstützungen durch Auswilderung handaufgezogener Gössel einschließt, drei adulte Wildvögel und zwei handaufgezogene subadulte Vögel, mit Satellitensendern versehen. Die besenderten Streifengänse wurden an den Hochgebirgsseen Son Kul und Chatyr Kul (Tienschan) in die Freiheit entlassen. Von diesen Vögeln konnten über das französische ARGOS-System insgesamt mehr als 5.000 Lokalisationen empfangen werden. Die Einzeltiere trugen jedoch in sehr unterschiedlichem Maße zur Datengewinnung bei. Ein Sender fiel bereits nach acht Wochen noch am Freilassungsort aus, ein anderer arbeitete dagegen über einen Zeitraum von mehr als zwei Jahren sehr zuverlässig. Anhand der auf diese Weise gewonnenen satellitentelemetrischen Daten werden in dieser Arbeit die Zugwege und die Überwinterungsräume sowie die zeitlichen Zugmuster von vier kirgisischen Streifengänsen im Detail beschrieben.

Die vier Streifengänse, drei adulte Wildvögel und ein handaufgezogener Jungvogel, nutzten überraschenderweise sehr unterschiedliche Zugwege und Überwinterungsgebiete. Zwei adulte Vögel überwinterten im südlichen Pakistan, der dritte im indisch-pakistanischen Grenzgebiet nahe Lahore, während sich der Jungvogel westwärts wandte und in Usbekistan überwinterte, wo die Art bisher noch nie nachgewiesen wurde. Im Gegensatz zu den Adulten, die längere Rastzeiten im südlichen Tadshikistan bzw. in Tibet einlegten, erreichte der Jungvogel sein Überwinterungsgebiet in einem Non-Stop-Flug über $790 \mathrm{~km}$ innerhalb eines Tages. Die adulten Vögel bewältigten ihre etwa 1.280 bis $1.550 \mathrm{~km}$ langen Zugwege sowohl im Frühahr als auch im Herbst stets in zwei Etappen mit Zwischenstopps von 32-46 Tagen beim Wegzug und 16-23 Tagen beim Heimzug. An Zugtagen entwickelten die Vögel regelmäßig Fluggeschwindigkeiten von etwa $700 \mathrm{~km} / \mathrm{Tag}$, wobei selbst höchste Regionen von Himalaja, Hindukusch, Tienschan und Karakorum überflogen wurden. Die zeitlichen Zugabläufe differierten recht stark zwischen den einzelnen Individuen und beim selben Individuum auch zwischen verschiedenen Jahren.

Diese satellitentelemetrischen Befunde werden zusammen mit den wenigen vorliegenden Ringfunden sowie mit Feldbeobachtungen hinsichtlich einer generellen Zugstrategie als Anpassung an den Hochgebirgslebensraum der Art diskutiert.

Acknowledgments Thanks to the kind support of the German MaxPlanck-Society, Vogelwarte Radolfzell, satellite transmitters became available to conduct this study. We are particularly thankful to Dr. E. Kreuzberg-Muchina, Dushanbe, Dr. V. Toropova, Bishkek, and Prof. A. Kovshar, Almaty, who provided unpublished information on current phenomena in Central Asian waterfowl and submitted additional data on earlier ring recoveries. U. Querner, Radolfzell, continuously assisted the data transfer and commented on the findings with his great experience. Owing to the kind assistance of Dr. J. Shergalin, Tallinn, Russian publications became accessible. A. Bräunlich, Berlin, and A. Globig, Tremt, provided valuable comments on earlier versions of this paper. For catching and marking wild bar-headed geese, as well as for any activities inside areas protected by nature conservation law, official permissions were granted by the state nature conservation authorities of Kyrgyzstan. Many thanks as well to the two anonymous reviewers, who provided invaluable advice for improving earlier versions of the manuscript.

\section{References}

Abdusalyamov IA (1971) The Fauna of the Tajik SSR. I. Birds (in Russian). Dushanbe

Ali S, Ripley SD (1987) Handbook of the birds of India and Pakistan. Oxford University Press, New Delhi

ARGOS (2007) User Manual, Service Argos. Toulouse. http://www. argossystem.org/documents/userarea/argos_manual_en.pdfCLS/

Berthold P (2007) Vogelzug. Eine aktuelle Gesamtübersicht. Wissenschaftliche Buchgesellschaft, Darmstadt

BirdLife International (2000) Threatened birds of the world. Lynx Edicions and BirdLife International, Barcelona and Cambridge

Bishop MA, Song Y, Canjue Z, Gu B (1997) Status and distribution of bar-headed geese Anser indicus wintering in south-central Tibet. Wildfowl 48:118-126

Black JM, Owen M (1989) Agonistic behaviour in barnacle goose flocks: assessment, investment and reproductive success. Anim Behav 37:199-209

Black CP, Tenny SM (1980) Oxygen transport during progressive hypoxia in high-altitude and sea-level waterfowl. Respir Physiol 39:217-239

Borodin AM, Bannikov AG, Sokolov WE (eds) (1985) Red data book of the U.S.S.R. (Krasnaya Kniga SSSR), vol 1 (Animals). Nauka, Moscow

Borshonov BB (1978) On flights of bar-headed geese to Taimyr peninsula (in Russian). Novosib Naucnotech Bull NIIS 15:44-46

Braunitzer G, Hiebl I (1988) Molekulare Aspekte der Höhenatmung von Vögeln. Hämoglobine der Streifengans (Anser indicus), der Andengans (Chloephaga melanoptera) und des Sperbergeiers (Gyps rueppellii). Naturwissenschaften 75:280-287

Butler PJ, Bishop CM (2000) Flight. In: Whittow GC (ed) Avian physiology. Academic Press, San Diego 
Choudhury A (1997) The bar-headed goose in north-eastern India and Bhutan. J Ecol Soc 10:17-19

Collar NJ, Andrew P (1988) Birds to watch-the ICBP world checklist of threatened birds. ICBP Technical Publication no. 8, Cambridge

Collar NJ, Crosby MJ, Stattersfield AJ (1994) Birds to watch 2-the world list of threatened birds. Birdlife International, Birdlife Conservation Series no. 4, Cambridge

Danilov-Danilian VI (ed) (2001) Red data book of the Russian federation: animals. Nauka, Moscow

Del Hoyo J, Elliott A, Sargatal J (1992) Handbook of the birds of the world, vol.1. Lynx Edicions, Barcelona

Dolnik VR (1990) Bird migration across arid and mountainous regions of middle Asia and Kazakhstan. In: Gwinner E (ed) Bird migration: the physiology and ecophysiology. Springer, New York

Dunning JB (1993) CRC handbook of avian body masses. CRC Press, London, Tokyo

Eichhorn G, Drent RH, Stahl J, Leito A, Alerstam T (2009) Skipping the Baltic: the emergence of a dichotomy of alternative spring migration strategies in Russian barnacle geese. J Anim Ecol 78:63-72. doi:10.1111/j.1365-2656.2008.01485

Elphick J (1995) Collins atlas of bird migration. Harper \& Collins, London

Gudmundsson GA, Benvenuti S, Alerstam T, Papi F, Lilliendahl K, Akesson S (1995) Examining the limits of flight and orientation performance: satellite tracking of brent geese migrating across the Greenland ice-cap. Proc R Soc Lond 261:73-79

Hays G, Akesson S, Godley B, Luschi P, Santridrian P (2001) The implications of location accuracy for the interpretation of satellite-tracking data. Anim Behav 61:1035-1040

Javed S, Takekawa JY, Douglas DC, Rahmani AR, Kanai Y, Nagendran M, Choudhury BC, Sharma S (2000) Tracking the spring migration of a bar-headed goose (Anser indicus) across the Himalaya with satellite telemetry. Glob Environ Res 4:195206

Kaatz M (2004) Der Zug des Weißstorchs Ciconia ciconia auf der europäischen Ostroute über den Nahen Osten nach Afrika. Ph.D. thesis, Martin-Luther-University, Halle-Wittenberg, Germany, p 163

Kear J (2005) Bird families of the world. Ducks, geese and swans, vol. 1. University Press, Oxford

Knystaustas A (1993) Birds of Russia. Harper Collins, London

Kydyraliev AK (1967) Bar-headed geese (Anser indicus) in the TianShan mountains (in Russian). Ornitologiya 8:245-253

Kydyraliev AK (1973) Waterfowl of the central Tian-Shan (in Russian). Frunse

Kydyraliev AK, Abdusalyamov IA (1979) Migrations of bar-headed goose. In: Ilyichev WD (ed) Migrations of birds of eastern Europe and Northern Asia. Nauka, Moscow

Lorentsen SH, Oien JI, Aarvak T (1998) Migration of Fennoscandian lesser white-fronted geese Anser erythropus mapped by satellite telemetry. Biol Conserv 84:47-52
Lu J (1997) Distribution of bar-headed goose in China. Ecol Soc 10:8-9

McClure HE (1998) Migration and survival of the birds of Asia. White Lotus Press, Bangkok

McKinnon J, Phillips K (2000) A field guide to the birds of China. Oxford University Press, Oxford

Melnikov U (1997) Rare geese species in the Baikal area: distribution and occurrence (in Russian). Russ J Ornithol Express Issue 21:14-19

Mineev EY, Mineev YN (2000) Bar-headed geese Eulabeia indica in the Bolshesemelskaya tundra (in Russian). Russ J Ornithol Express Issue 113:22

Ming M, Dai C (1999) Breeding ecology of bar-headed goose in Tianshan, Xinjiang. Casarca 5:177-181

Miyabayashi Y, Mundkur T (1999) Atlas of key sites for Anatidae in the east Asian flyway. Tokyo, Wetlands International-Japan and Kuala Lumpur, Wetlands International-Asia Pacific

Newton I (2008) The migration ecology of birds. Migration systems and population limitation. Academic Press, London, pp 697-822

Perennou CT, Mundkur T, Scott DA, Follestad AN, Kvenild L (1994) The Asian waterfowl census 1987-1991: distribution and status of Asian waterfowl. Asian Waterfowl Bureau, publication no. 86, Kuala Lumpur

Prevett JP, McInnes CD (1980) Family and other social groups in snow geese. Wildl Monogr 71:1-46

Roberts TI (1991) The birds of Pakistan, volume 1. Regional studies and non-passeriformes. Oxford University Press, Oxford

Rutschke E (1997) Wildgänse. Lebensweise-Schutz-Nutzung. Paul Parey, Berlin

Saunders DK, Fedde MR (1991) Physical conditioning: effect on the myoglobin concentration in skeletal and cardiac muscle of barheaded geese. Comp Biochem Physiol A Comp Physiol 100:349-352

Selesnev VF (1976) On the bar-headed goose in Tajikistan (in Russian). In: Gladkov NA (ed) Rare, extinct and less investigated birds of the U.S.S.R. Nauka, Ryasan

Swan LW (1970) Goose of the Himalayas. Nat Hist 79:68-74

Syroechkovskyi EE, Rogacheva EW (1995) Red data book of Krasnoyarsk county (in Russian). Krasnoyarsk

The U.S. Geological Survey (USGS) (2006) Bar-headed goose migration over the Himalaya Cordellera 2005. Western Ecological Research Center, Sacramento, USA. http://www.werc.usgs. gov/sattrack/project2005.html

Yakovlev AP (1997) Current population status of the bar-headed Goose (Anser indicus) in Kirgizia and its preservation. Casarca $3: 260-270$

Zhang J, Hua Z, Tame RH, Lu G, Zhang R, Gu X (1996) The crystal structure of a high oxygen affinity species of haemoglobin (barheaded goose haemoglobin in the oxy form). J Mol Biol 255:484-493 